\title{
A Comparative Study on the Modalities of Treatment in Liver Abscess and Their Outcome
}

\author{
Dr.V.Lekshmi Narayani ${ }^{1}$, Dr.P.Kannan ${ }^{2}$ \\ I'Associate Professor Of Surgery/ Government Medical College \& ESI Hospital,Coimbatore, India.) \\ ${ }^{2}$ (Assistant Professor Of Surgery/ Government GMKM Medical College Hospital, Salem, India)
}

\begin{abstract}
Objectives: To compare the outcome of medical treatment and surgical treatment in liver abscess. Keywords: Liver Abscess, Chemotherapy-Percutaneous, Aspiration, Laparatomy And Drainage

Methods: This was a hospital based prospective study over a period of 18months in cmch Coimbatore.

Results: Out of 50 patients 17 patients were subjected to medical treatment alone and 6 of them needed aspiration because of poor response to antibiotic alone(failure rate of 36\%) 26 patients were treated with aspiration and antibiotics showing 55\%sucess rate after single aspiration,79\%after two aspiration And $97 \%$ sucess rate after3 aspiration tube drainageTubedrainage with antibiotics was tried in failure of Percutaneous aspiration with antibiotics in one case with Success rate of 100\%.Laparotomy and drainage with antibiotics in cases with ruptured liver abscess with $33 \%$ of success rate.

Conclusion: Liver abscess without complication may be treated with percutaneous aspiration and chemotherapy. Only complicated cases need laparotomy and drainage.
\end{abstract}

\section{Introduction}

Liver abscess was being considered as a major illness since ancient days i.e from the era of HIPPOCRATES(1)The early diagnosis is required for earlier and effective treatment.The treatment of liver abscess has evolved greatly since1938When Ochsneret al(2) demonstrated the reduction in mortality Associated with operative drainage for all liver abscesses.Since mcfadzean et al(3) first published a series on treatment of d1953 a shift toward non-operative management occurred. A series by Berger Osborne in 1982 (4) demonstrated the treatment of 62 patients with hepatic abscess with antibiotic therapy and needle aspiration. The mortality rate was $4 \%$. Jerzof et al (4) have pointed out the percutaneous drainage is similar to minimally invasive surgical means drainage. Treatment of liver abscess differ depending upon the size of abscess, size of abscess, with or without complication at presentation. Early diagnosis is required to prevent rupture of abscess as well as for treatment.The invent of ULTRASONOGRAM and CT SCAN help for early diagnosis.

\section{Objectives}

1.To determine the outcome of medical management in liver abscess.

2.To determine the outcome of surgical drainage in liver abscess

3.To compare the outcome of both modes of treatment.

\section{Materials And Methods:}

A prospective study over a period of 18 months done in $\mathrm{CMCH}$ Coimbatore.

In this study 50 patients were subjected to detailed History clinical examination routine investications ,radiological investigation like USG ABDOMEN AND PELVIS,computerised tomographic scan .USGAbdomen was done in all patients.CT SCAN was done in patients with multiple liver abscesses, caudate lobe abscess, left lobe abscess and ruptured liver abscesses with presenting as peritonitis and sepsis $(8,9)$. After investigations depending upon the number and size of the cavity, nature of illness, location of abscess cavity patients were categorized as follows;

1.Antibioticsalone; less than $200 \mathrm{ml}$ The drugs used were ampicillin+aminoglicosides+metronidazole

Third generationcephalosporins and metronidazole

2.Patients with following criteria were taken for percutaneous aspiration.

1Patients who continued/ worsened to treatment with antibiotics alone.

2.Liver abscess with more than $5 \mathrm{~cm}$ in size.

3.Clinical or ultrasonogram features suggest impending rupture.

3. Open drainage was done in patients falling in Kapoor's criteria.

Thick pus which could not be aspirated 
Patients with ongoing sepsis even after antibiotics and percutaneous aspiration. Multilobular abscess Abscess in the left lobe. Ruptured abscess. After aspiration according to culture and sensitivitythe antibiotics were changed. Before aspiration inj.vitaminekprophylaxis for 3 days given. Inclusion criteria. Patients more than 18 years Patients presenting with liver abscess. Exclusion criteria Patients less than 18 years Pregnancy

\section{Results}

\section{Mode of presentation.}

\begin{tabular}{|l|l|l|l|}
\hline Sl.no & Involved part & No.of patient & $\%$ \\
\hline 1 & Only right lobe & 41 & 82 \\
\hline 2 & Only left lobe & 4 & 8 \\
\hline 3 & Both lobes & 4 & 8 \\
\hline 4 & Caudate lobe & 1 & 2 \\
\hline
\end{tabular}

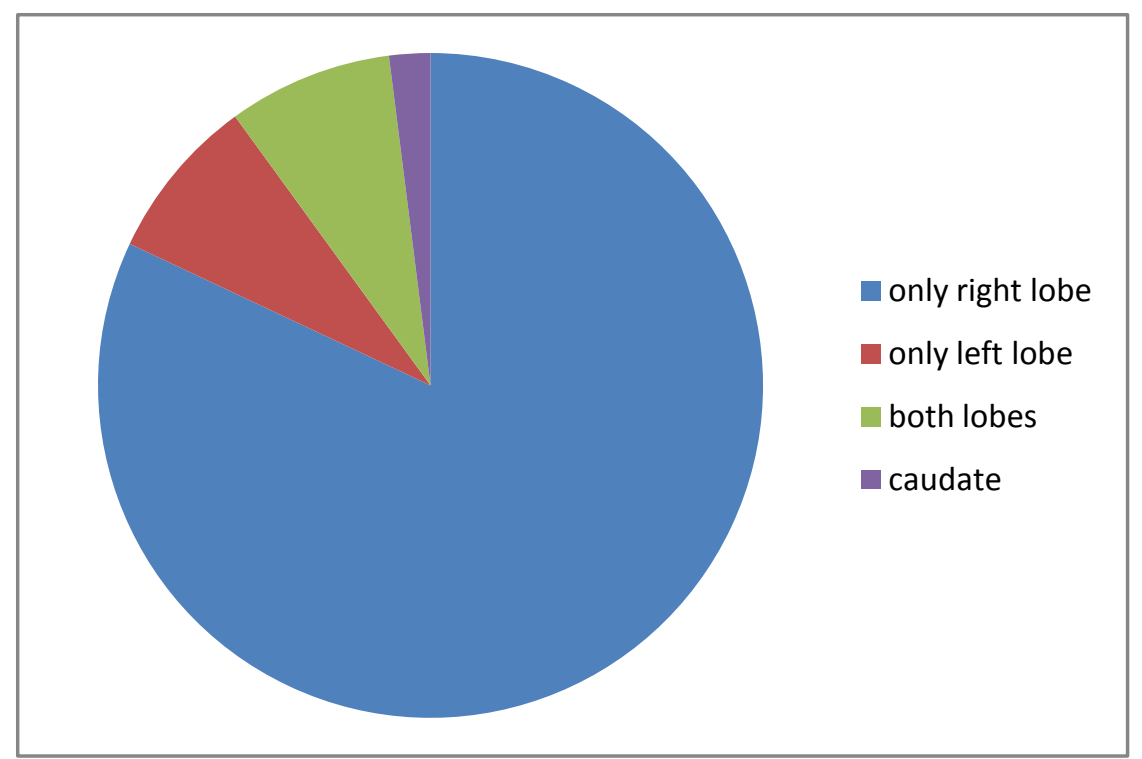

2.Number of abscess cavity

\begin{tabular}{|l|l|l|l|l|l|}
\hline Si.no & No of cavity & Right & Left & Caudate & Both lobe \\
\hline 1 & Single & 36 & 4 & 1 & 0 \\
\hline 2 & Two & 0 & 0 & 0 & 4 \\
\hline 3 & Multiple & 5 & 0 & 0 & 0 \\
\hline \multicolumn{7}{|l|}{} \\
\hline
\end{tabular}

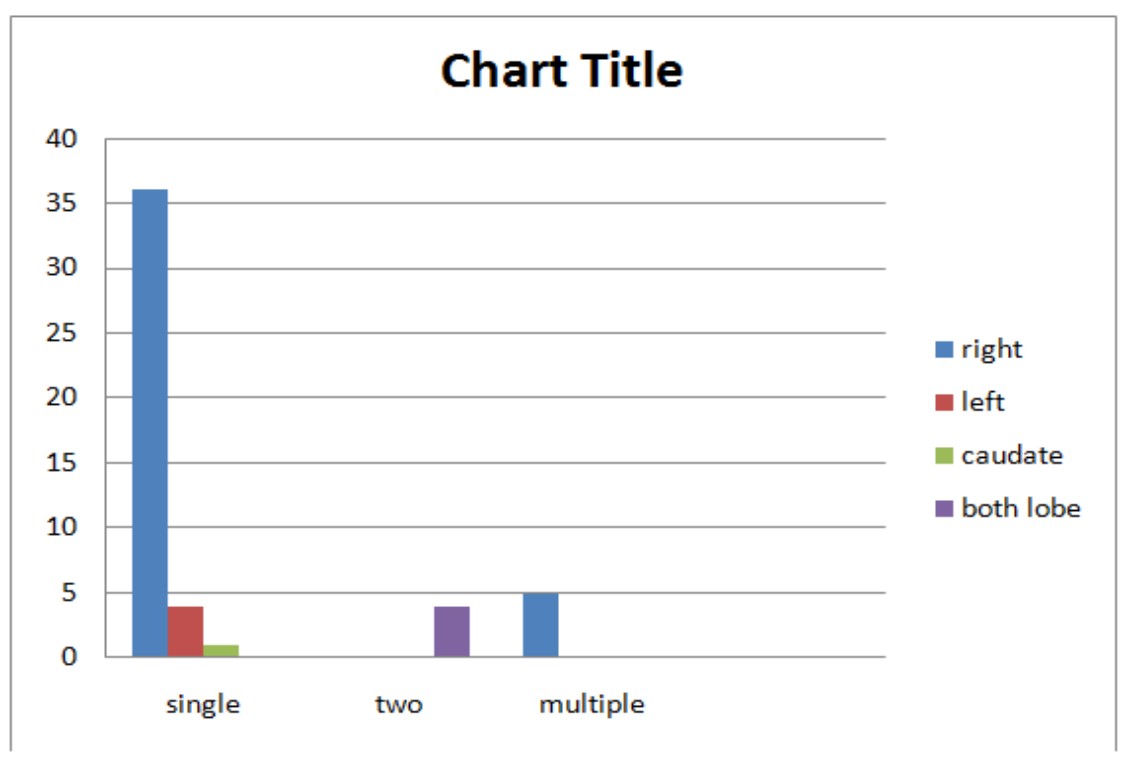


3.Number of cavity and its mode of treatment

\begin{tabular}{|l|l|l|l|l|l|}
\hline Sl.no & $\begin{array}{l}\text { No of } \\
\text { cavity }\end{array}$ & IVantibitics alone & $\begin{array}{l}\text { Aspiration+ } \\
\text { antibiotics }\end{array}$ & $\begin{array}{l}\text { Tube } \\
\text { Drainage+ } \\
\text { antibiotics }\end{array}$ & $\begin{array}{l}\text { Laparatomy+ } \\
\text { Drain+Antibiotics }\end{array}$ \\
\hline 1 & Multiple & 5 & 3 & 0 & 0 \\
\hline 2 & Two & 0 & 4 & 0 & 0 \\
\hline 3 & Single & 12 & 26 & 4 & 3 \\
\hline
\end{tabular}

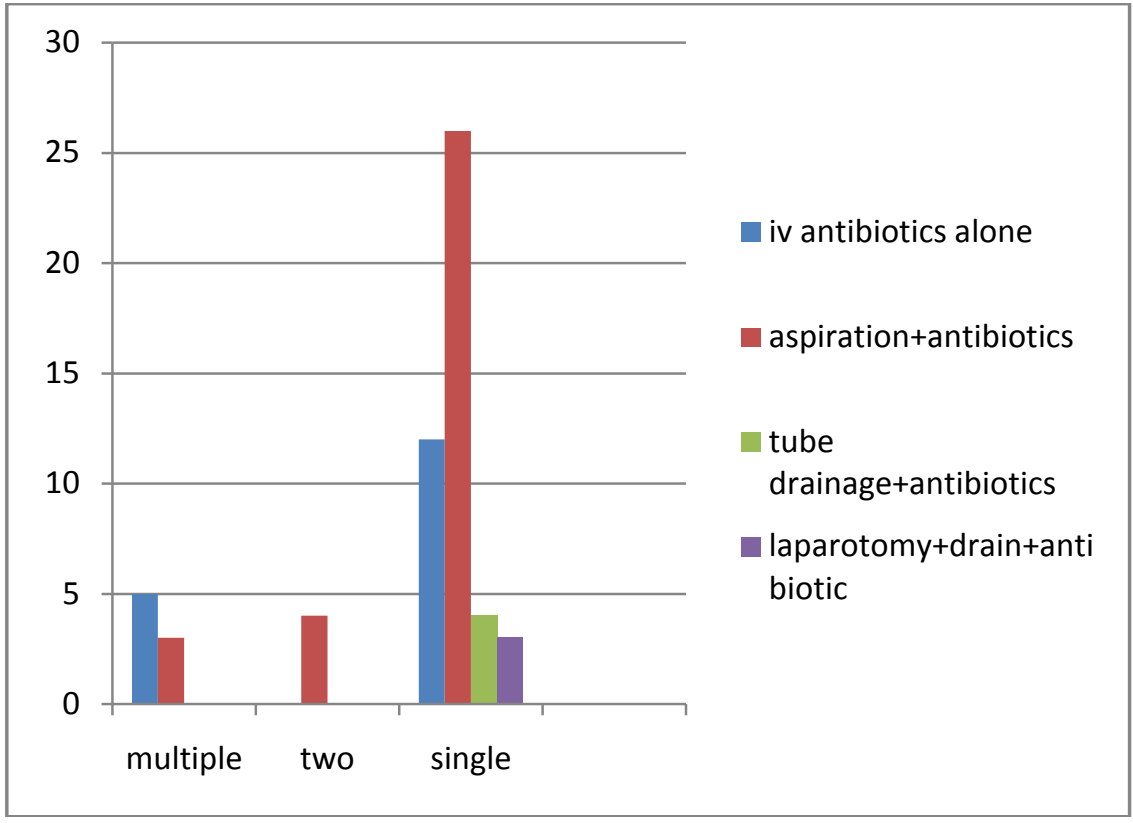

\section{Results}

The data was tabulated and analysed as follows:

Table 1: Mode Of Presentations

\begin{tabular}{|c|c|c|c|}
\hline Sl.No & Involved Part & N.ofPts & \% \\
\hline 1 & Only right lobe & 41 & 82 \\
\hline 2 & Only left lobe & 4 & 8 \\
\hline 3 & Both lobes & 4 & 8 \\
\hline 4 & Caudate & 1 & 2 \\
\hline
\end{tabular}

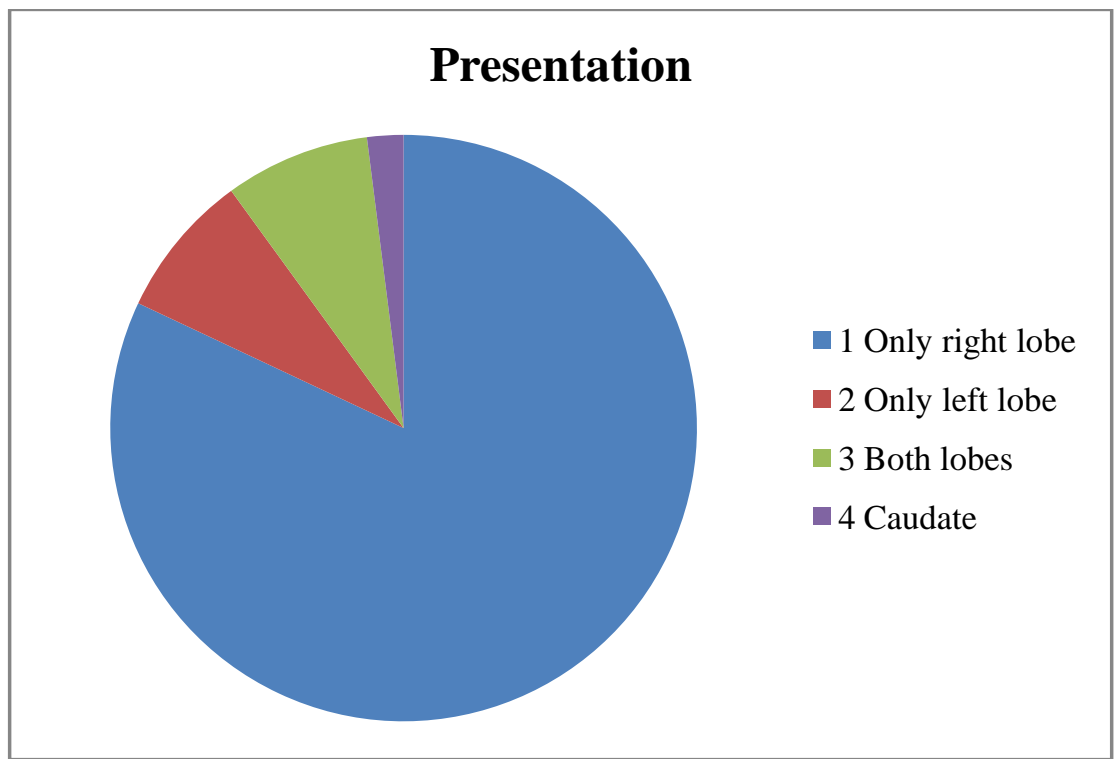


Table 2: Number Of Abscess Cavity

\begin{tabular}{|c|c|c|c|c|c|}
\hline Sl.No & No of cavity & Right & Left & Caudate & Both Lobe \\
\hline 1 & Single & 36 & 4 & 1 & 1 \\
\hline 2 & Two & 0 & 0 & 0 & 4 \\
\hline 3 & Multiple & 5 & 0 & 0 & 0 \\
\hline
\end{tabular}

Table 3: Number Of Cavity And Its Mode Of Treatement

\begin{tabular}{|c|c|c|c|c|c|}
\hline Sl.No & $\begin{array}{c}\text { No of } \\
\text { cavity }\end{array}$ & $\begin{array}{c}\text { I.V.Antibiotics } \\
\text { Alone }\end{array}$ & $\begin{array}{c}\text { Aspiration } \\
+ \\
\text { Antibiotics }\end{array}$ & $\begin{array}{c}\text { Tube } \\
\text { drainage + } \\
\text { Antibiotic }\end{array}$ & $\begin{array}{c}\text { Laparotomy + } \\
\text { Drain + } \\
\text { Antibiotics }\end{array}$ \\
\hline 1 & Multiple & 5 & 3 & 0 & 0 \\
\hline 2 & Two & 0 & 4 & 0 & 0 \\
\hline 3 & Single & 12 & 26 & 4 & 3 \\
\hline
\end{tabular}

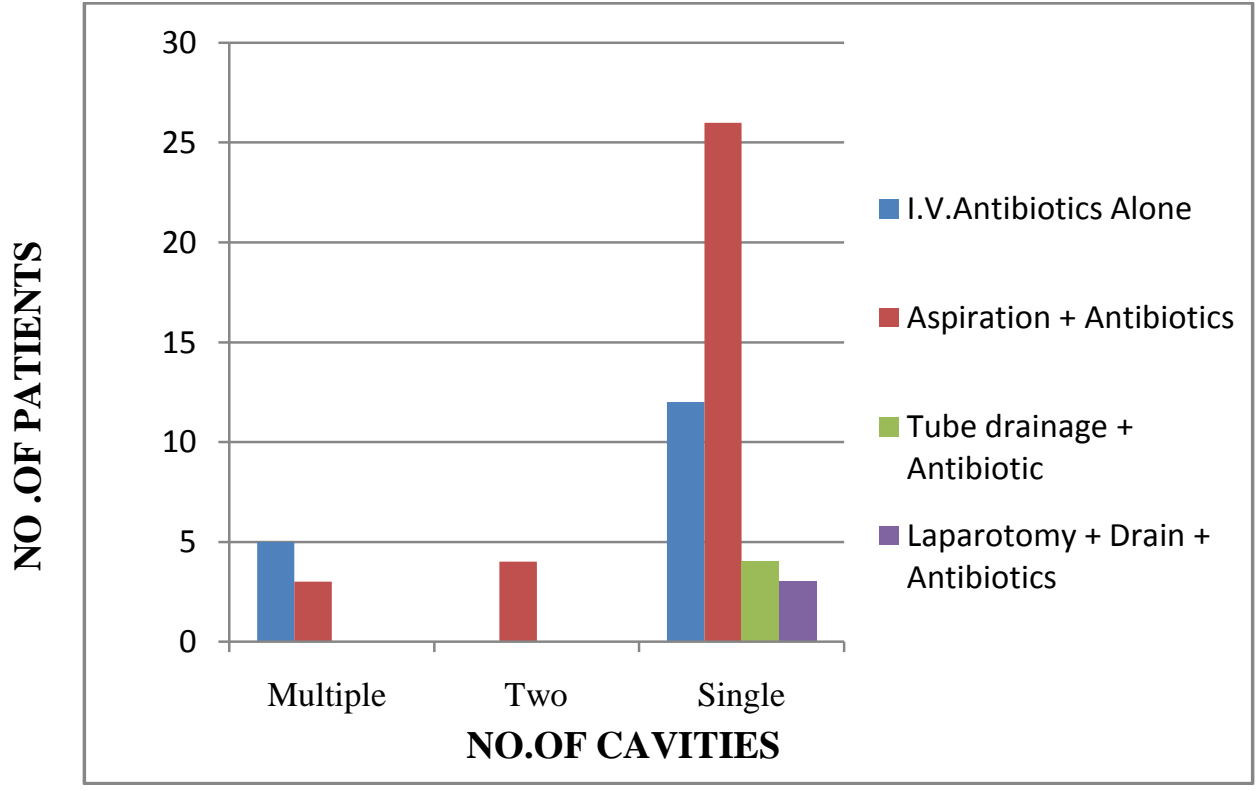

Table 4: Mode Of Outcome With Parenteral Antibiotics Alone

\begin{tabular}{|c|c|c|c|c|}
\hline Sl.No & Lobe & No.of Patients & Cured & Failure \\
\hline 1 & Right & 15 & $10(66.6 \%)$ & $5(33 \%)$ \\
\hline 2 & Left & 1 & 0 & $0(100 \%)$ \\
\hline 3 & Both & 0 & 0 & 0 \\
\hline 4 & $\begin{array}{c}\text { Caudate } \\
\text { (small abscess) }\end{array}$ & 1 & $1(100 \%)$ & 0 \\
\hline
\end{tabular}

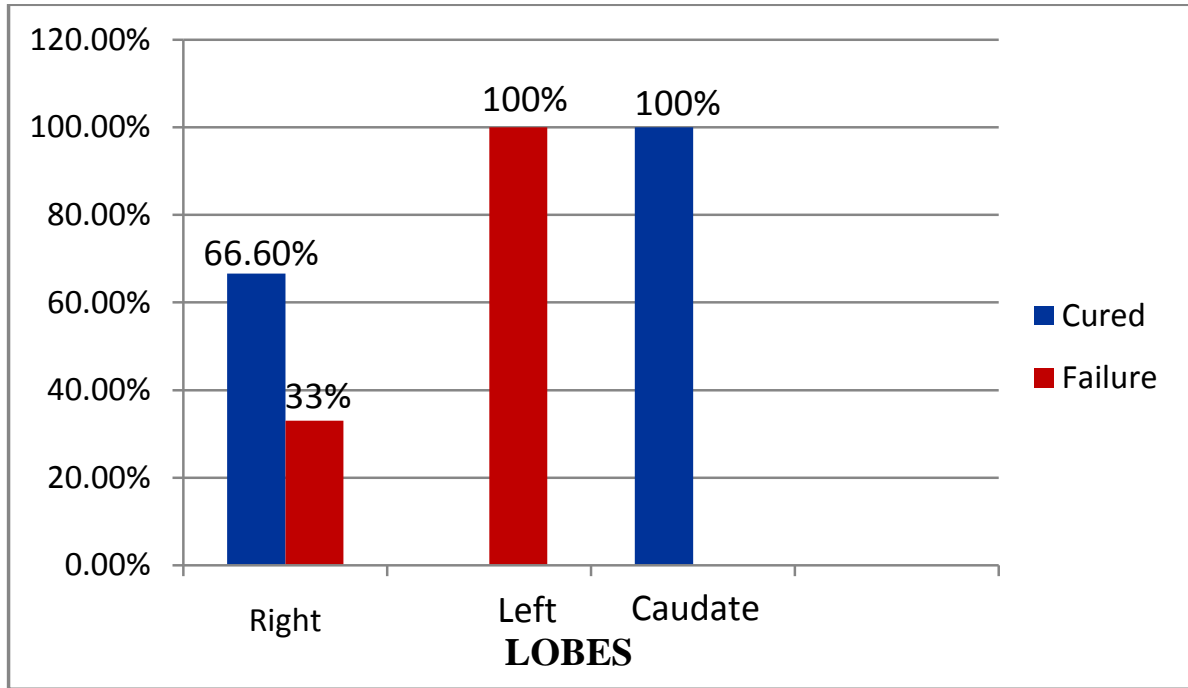

Table 5: Number Of Aspiration 


\begin{tabular}{|c|c|c|c|c|c|}
\hline Sl.No & Lobe & $\begin{array}{c}\text { No.of } \\
\text { Patients }\end{array}$ & $\begin{array}{c}\mathbf{1}^{\text {st }} \\
\text { Aspiration }\end{array}$ & $\mathbf{2}^{\text {nd }}$ Aspiration & $\mathbf{3}^{\text {rd }}$ Aspiration \\
\hline 1 & Right & 27 & 27 & 9 & 4 \\
\hline 2 & Left & 2 & 2 & 1 & 1 \\
\hline 3 & Both & 4 & 4 & 4 & 2 \\
\hline
\end{tabular}

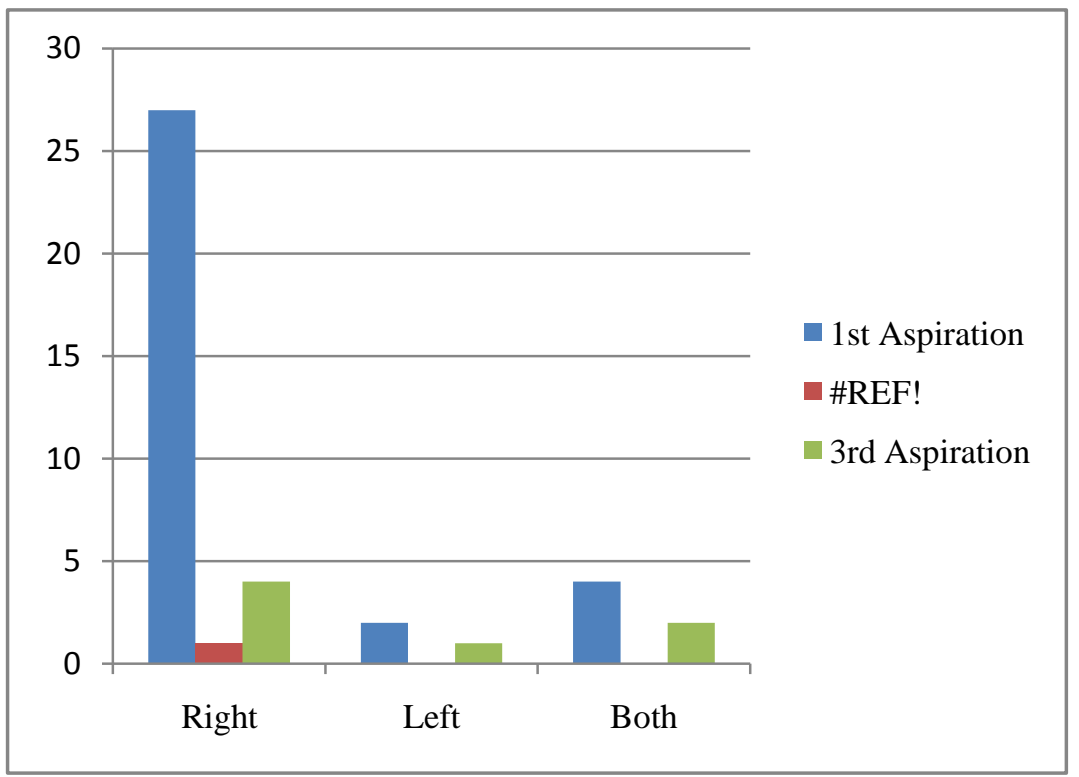

Table 6: Outcome After Each Aspiration

\begin{tabular}{|c|c|c|c|c|}
\hline Sl.No & Lobe & After 1 $^{\text {st }}$ (Cure rate) & $\begin{array}{c}\text { After 2 }^{\text {nd }} \\
(\text { Cure rate) }\end{array}$ & $\begin{array}{c}\text { After3 }^{\text {rd }} \\
\text { (Cure rate) }\end{array}$ \\
\hline 1 & Right(27) & $17(63.6 \%)$ & $22(81 \%)$ & $26(96 \%)$ \\
\hline 2 & Left (2) & $1(50 \%)$ & $1(50 \%)$ & $2(100 \%)$ \\
\hline 3 & Both(4) & 0 & $2(50 \%)$ & $4(100 \%)$ \\
\hline
\end{tabular}

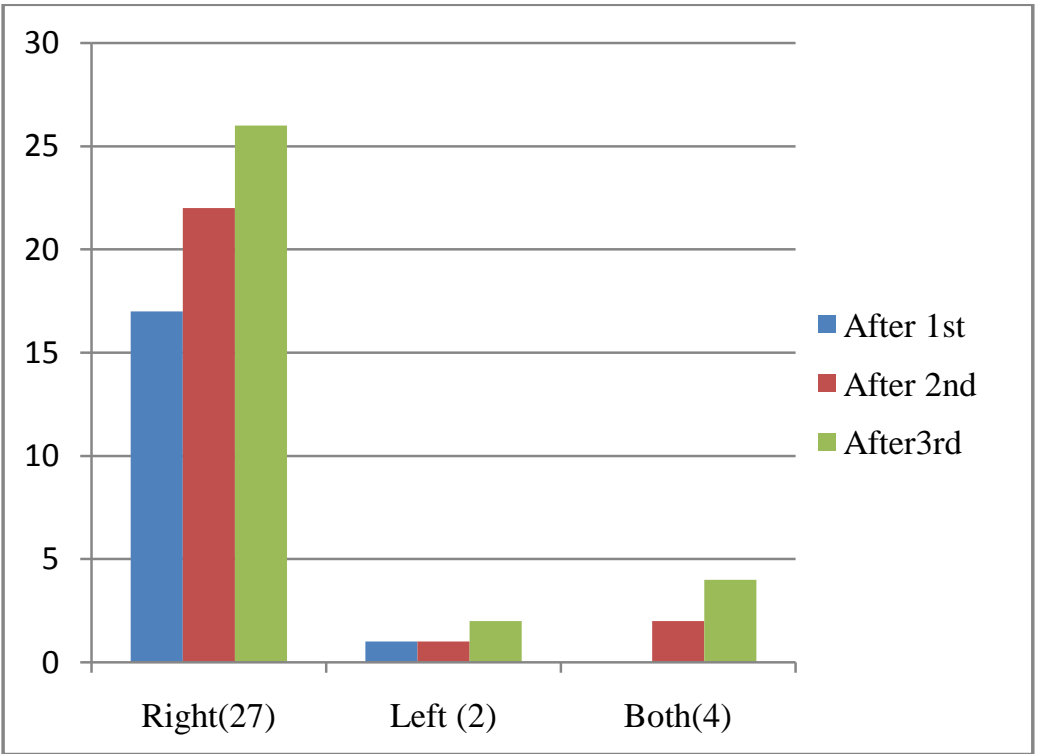

Table 7: Tube Drainage With Antibiotics And Its Outcome

\begin{tabular}{|c|c|c|}
\hline Sl.No & Lobe & Outcome \\
\hline 1 & Right (2) & 2 (cured) \\
\hline 2 & Left (2) & 2 (cured) \\
\hline
\end{tabular}


Table 8: Laparotomy And Drainage With Antibiotics

\begin{tabular}{|c|c|c|c|}
\hline Sl.No & No.of Patients & Cured & Failure \\
\hline 1 & 3 & $1(33)$. & $2(66.6 \%)$ \\
\hline
\end{tabular}

Table 9: Location Of Abscess Cavity And Its Management

\begin{tabular}{|c|c|c|c|c|c|c|}
\hline $\begin{array}{c}\text { S.N } \\
\text { o }\end{array}$ & Lobe & $\begin{array}{l}\text { No Of } \\
\text { Patients }\end{array}$ & $\begin{array}{c}\text { Parenteral } \\
\text { Antibiotics } \\
\text { Alone }\end{array}$ & $\begin{array}{c}\text { Aspiratio } \\
\mathbf{n} \\
+ \\
\text { Antibioti } \\
\text { cs }\end{array}$ & $\begin{array}{c}\text { Tube } \\
\text { Drainage + } \\
\text { Antibiotics }\end{array}$ & $\begin{array}{c}\text { Laparotomy } \\
+ \text { Drainage } \\
+ \\
\text { Antibiotics }\end{array}$ \\
\hline 1 & $\begin{array}{l}\text { Right } \\
\text { Single } \\
\text { Multipl } \\
\mathrm{e}\end{array}$ & $\begin{array}{l}36 \\
05\end{array}$ & $\begin{array}{l}10 \\
05\end{array}$ & $\begin{array}{l}24 \\
03\end{array}$ & $\begin{array}{l}02 \\
00\end{array}$ & $\begin{array}{l}03 \\
00\end{array}$ \\
\hline 2 & $\begin{array}{l}\text { Left } \\
\text { Single }\end{array}$ & 04 & 01 & 02 & 02 & 00 \\
\hline 3 & Both & 04 & 00 & 04 & 00 & 00 \\
\hline 4 & $\begin{array}{l}\text { Cauda } \\
\text { te }\end{array}$ & 01 & 01 & 00 & 00 & 00 \\
\hline
\end{tabular}

Table 10: Lobar Involvement, Treatment And Its Outcome

\begin{tabular}{|c|c|c|c|c|c|}
\hline \multirow[t]{2}{*}{ Lobe Involved } & \multirow{2}{*}{$\begin{array}{c}\text { Mode of treatment } \\
\text { (no) }\end{array}$} & \multicolumn{4}{|c|}{ Outcome } \\
\hline & & \multicolumn{2}{|c|}{ Cured } & \multicolumn{2}{|c|}{ Failure } \\
\hline \multirow[t]{3}{*}{ Right lobe } & $\begin{array}{c}\text { Parenteral } \\
\text { antibiotics alone- } \\
\text { single (10) } \\
-\quad \text { multiple }\end{array}$ & $\begin{array}{l}8 \\
2\end{array}$ & $\begin{array}{l}80 \% \\
40 \%\end{array}$ & 3 & $\begin{array}{l}20 \% \\
60 \%\end{array}$ \\
\hline & $\begin{array}{l}\text { After } 1 \\
\text { Aspiration } \\
2 \\
\text { Aspiration } \\
3 \\
\text { Aspiration } \\
\end{array}$ & $\begin{array}{l}17 \\
23 \\
26\end{array}$ & $\begin{array}{l}63 \% \\
85 \% \\
96 \%\end{array}$ & $\begin{array}{c}10 \\
4 \\
1\end{array}$ & $\begin{array}{c}37 \% \\
15 \% \\
4 \%\end{array}$ \\
\hline & Tube (2) & 2 & $100 \%$ & 0 & $0 \%$ \\
\hline \multirow[t]{3}{*}{ Left lobe } & $\begin{array}{l}\text { Antibiotics alone } \\
\text { (1) }\end{array}$ & 0 & $0 \%$ & 1 & $100 \%$ \\
\hline & $\begin{array}{l}\text { After } 1 . \\
\text { Aspiration } \\
2 . \\
\text { Aspiration } \\
3 . \\
\text { Aspiration } \\
\end{array}$ & $\begin{array}{l}1 \\
1 \\
2\end{array}$ & $\begin{array}{c}50 \% \\
50 \% \\
100 \%\end{array}$ & $\begin{array}{l}1 \\
1 \\
0\end{array}$ & $\begin{array}{c}50 \% \\
50 \% \\
0 \%\end{array}$ \\
\hline & Tube (2) & 2 & $100 \%$ & 0 & $0 \%$ \\
\hline \multirow[t]{2}{*}{ Both lobes } & Antibiotics-alone & - & - & - & - \\
\hline & $\begin{array}{l}\text { After } \\
\text { 1Aspiration } \\
\text { 2Aspiration } \\
\text { 3Aspiration }\end{array}$ & $\begin{array}{l}0 \\
2 \\
4\end{array}$ & $\begin{array}{c}0 \% \\
50 \% \\
100 \%\end{array}$ & $\begin{array}{l}4 \\
2 \\
0\end{array}$ & $\begin{array}{c}100 \% \\
50 \% \\
0 \%\end{array}$ \\
\hline $\begin{array}{l}\text { Caudate (small } \\
\text { abscess) }\end{array}$ & Antibiotics alone & 1 & $100 \%$ & 0 & $0 \%$ \\
\hline
\end{tabular}

\section{Discussion}

Hepatic abscess was first described by HIPPOCRATES around4000BC.(1) OCHSNER's review of 47 cases of pyogenic abscess were treated by open surgical drainage. Advances in diagnostic and therapeutic radiology with improvement in microbiological identification and therapy decreased the mortality rates to<5-30\%(2). In this series50 patients were studied and 2 died.USG ANDCTscan of abdomanwere the gold standard diagnostic modalities. The antibiotics Ampicillin+Aminoglycosides+Metronidazoleor third generation Cephelosporins+Metronidazolewere given. Antibiotics were changed after aspiration according to culture and sensitivity. MALIK et al(5)reported their experience of managing 169 pyogenic liver abscesses .16 of which were treated with IV antibiotics alone for 2 weeks. This report was successful in only 6 of them the remaining 10 required open surgical drainage for control of sepsis.

BLESRMAN and Collegues reported a prospective randomized trial of patients with amoebic abscess treated with Metronidazole alone or withUSG guided aspiration plus medication. They advocated drug treatment alone for uncomplicated abscess with a diameter upto10 $\mathrm{cm}$ and located in right lobe of liver.(6). 
In our series17 patients were treated with antibiotics alone. Among this 11 pts were cured . 6 ts were converted into surgical methods of treatment. In this 11pts 8pts had right lobe abscesswith single cavity .2pts with multiple cavity and one with small caudate lobe abscess.

33 pts were treated with aspiration and antibiotics. After single aspiration with antibiotics18 pts got cured.At the end of 2 aspiration with antibiotics 26 pts were cured.After 3 aspiration with antibiotics32 pts got cured.Onept was changed to closed tube drainage as the size of abscess increases. 4 pts were treated with closed tube drainage with success rate of $100 \%$. 3pts were treated with laparotomy and drainage as the abscess was ruptured at presentation.2pts died 1 pt got cured.

\section{Conclusion}

Parenteral antibiotics alone without any drainage procedure has shownpoorresults.Only 17 pts were subjected to this and 6pts neededaspiration.Failure rate $36 \% /$ Percutaneous aspiration has better results with success rate of $55 \%$ with single aspirationwithantibiotisc,with success rate of $79 \%$ after 2 aspirations with antibiotics and successrate of $97 \%$ after 3 aspirations with antibiotics. Tube drainage with antibiotics showed $100 \% /$ success rate .Laparotomy with drainage done in ruptured abscess the success rate was $33 \%$.

\section{Reference}

[1]. Yost, Jon. "Amebiasis." Pediatrics in review/American Academy of Pediatrics 23.8 (2002): 293-294.

[2]. Malik, Ajaz A., et al. "Pyogenic liver abscess: Changing patterns in approach." World J GastrointestSurg 2.12 (2010): $395-401$.

[3]. Carachi, Robert. "Bailey and Love's Short Practice of Surgery 25th Edition." (2009): 48-48.

[4]. Ochsner, Alton, Michael DeBakey, and Samuel Murray. "Pyogenic abscess of the liver: II. An analysis of forty-seven cases with review of the literature." The American Journal of Surgery 40.1 (1938): 292-319.

[5]. McFadzean, A. J. S., K. P. S. Chang, and C. C. Wong. "Solitary pyogenic abscess of the liver treated by closed aspiration and antibiotics: a report of 14 consecutive cases with recovery." British Journal of Surgery 41.166 (1953): 141-152.

[6]. Blessmann, Joerg, et al. "Ultrasound patterns and frequency of focal liver lesions after successful treatment of amoebic liver abscess." Tropical Medicine \& International Health 11.4 (2006): 504-508.

[7]. Johannsen, Eric C., Costi D. Sifri, and Lawrence C. Madoff. "Pyogenic liver abscesses." Infectious disease clinics of North America 14.3 (2000): 547-563.

[8]. Kaplan, Gilaad G., Daniel B. Gregson, and Kevin B. Laupland. "Population-based study of the epidemiology of and the risk factors for pyogenic liver abscess." Clinical Gastroenterology and Hepatology 2.11 (2004): 1032-1038.

[9]. Thomas, P. G., and K. V. Ravindra. "Amoebiasis and biliary infection." Surgery of the Liver ad Biliary tract 3rd edition. New York, Saunders WB Imprint-Elsevier Science (2000): 916-918.

[10]. Sharma, M. P., et al. "Prognostic markers in amebic liver abscess: a prospective study." American Journal of Gastroenterology $91.12(1996)$. 